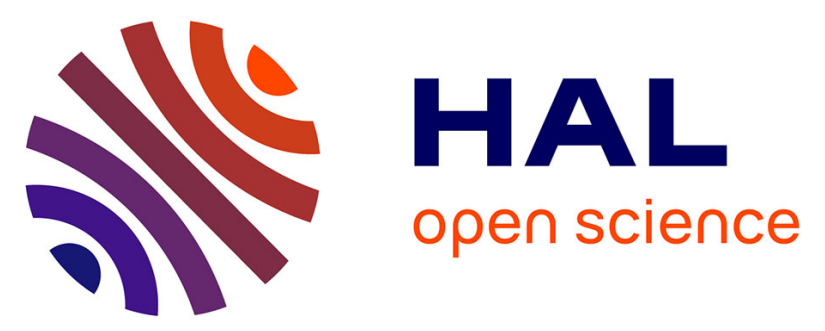

\title{
Narrating the Past and the Future: The Position of the religions orientales and the mystères païens in the Evolutionary Histories of Religion of Franz Cumont and Alfred Loisy \\ Annelies Lannoy, Corinne Bonnet
}

\section{To cite this version:}

Annelies Lannoy, Corinne Bonnet. Narrating the Past and the Future: The Position of the religions orientales and the mystères païens in the Evolutionary Histories of Religion of Franz Cumont and Alfred Loisy. Archiv für Religionsgeschichte, 2018, 20 (1), pp.157-182. 10.1515/arege-2018-0010 . hal-02171502

\author{
HAL Id: hal-02171502 \\ https://hal.science/hal-02171502
}

Submitted on 2 Jul 2019

HAL is a multi-disciplinary open access archive for the deposit and dissemination of scientific research documents, whether they are published or not. The documents may come from teaching and research institutions in France or abroad, or from public or private research centers.
L'archive ouverte pluridisciplinaire HAL, est destinée au dépôt et à la diffusion de documents scientifiques de niveau recherche, publiés ou non, émanant des établissements d'enseignement et de recherche français ou étrangers, des laboratoires publics ou privés. 
Annelies Lannoy \& Corinne Bonnet

Narrating the Past and the Future:

The Position of the religions orientales and

the mystères païens in the Evolutionary

Histories of Religion of Franz Cumont

and Alfred Loisy

\begin{abstract}
In their grand narratives on the ancient history of religions, the Belgian historian of religions, Franz Cumont (1868-1947) and his French colleague and correspondent, Alfred Loisy (1857-1940) both assigned a prominent place to the so-called pagan mystery religions. This paper seeks to identify the specific theories of religion and the deeper motivations underpinning Cumont's and Loisy's historiographical construction of the mystery cults as a distinct type of religion within their evolutionary accounts of the history of religions. Through a comparative analysis of their rich correspondence (1908-1940) and a selection of their publications, we demonstrate how their historical studies of the religious transformations in the Roman Empire, their in-depth dialogues in the troubled times in which they lived, and their philosophical views on the overall history and future of religion, were in fact mutually constitutive.
\end{abstract}

\title{
1 Introduction
}

Franz Cumont (1868-1947) and Alfred Loisy (1857-1940) were two eminent historians of religion with a particular interest in the relationship between Greco-Roman paganism and Early Christianity. Both scholars attributed a crucial role to the pagan mystery 'religions' in the religious transformations of the Roman Empire. ${ }^{1}$ They believed that the mysteries, with their focus on individual morality, spirituality and emotion, transformed 'traditional' paganism and prepared the coming of Christianity. $^{2}$ This family of religions was given a prominent position in their positivist

We would like to thank Danny Praet (Ghent University) for his insightful comments and suggestions on our paper, as well as the anonymous referee for his/her helpful suggestions.

1 For Cumont, see e. g.: Bonnet, Van Haeperen 2006; Bonnet 2011; Praet 2011; Praet 2014. For Loisy: Roessli 2013; Praet, Lannoy, 2017.

2 In the scientific interactions between Cumont and Loisy the focus is on the religions orientales (Cumont) and the mystères païens (Loisy) as an evolutionary phase in the progressive development of religion (cf. infra). By contrast, the framework of the Dekadenz of Roman pagan religion-which was also very widely used at that time to explain the 'triumph' of Christianity in Antiquity-is almost 
views on the religious evolution of mankind. Over the last few decades Cumont's Religions orientales and Loisy's Mystères païens have been the subject of critical scholarly attention. ${ }^{3}$ Our conception of these cults and their relation to Christianity has changed drastically since, but it is still instructive to revisit the late $19^{\text {th }}$ and early $20^{\text {th }}$ century historiography with the aim to understand the scientific narratives from within and, ultimately, to gain deeper insight into the process of writing history.

An important condition for understanding the intricate ways in which religions have been created by scientific historiography, is to have knowledge of the scientifictheoretical and socio-ideological profile of the historian. This reconstruction of the relationship between the author-subject and his/her object is a delicate matter, especially when the present of the subject has itself turned into a (more or less) distant past. ${ }^{4}$ Scholarship on Cumont and Loisy holds a unique position in late $19^{\text {th }}$ and early $20^{\text {th }}$ century intellectual history because of the wide array of documents available to study their thought. Cumont and Loisy not only expressed their views in publications, but also in a lively correspondence which has been preserved almost entirely. ${ }^{5}$ This correspondence started one year after Loisy's excommunication from the Catholic Church (1908), when Cumont wrote to Loisy to congratulate him upon his appointment to the chair of history of religions at the Collège de France (1909). In their letters the Belgian specialist in Mithras and the French expert on Early Christianity often discussed the pagan mystery cults and gave each other information on the genesis of and the strategies behind their publications (e.g. Lannoy 2013). Their letters furthermore uncover the theoretical and ideological grids framing their published work. Their intense discussions and frequent dissensions forced them to formulate and to come to terms with the often more implicit assumptions behind their scientific narratives.

In this respect, it is important to note that the Cumont-Loisy correspondence makes an original use of the Comtian religion de l'humanité notion. According to Comte's evolutionary theory, the history of religion develops progressively, towards higher spirituality, universality and morality, while man himself increasingly be-

completely absent from their scientific dialogue. This specific model of interpretation therefore lies beyond the scope of our article. For Cumont's ambivalent use of the Dekadenzidee, cf. Bonnet 2005, 102-104. 334-339.

3 See, among many others: Burkert 1987; Bonnet, Rüpke, Scarpi 2006; Bonnet, Pirenne-Delforge, Praet 2009; Scheerlinck, Praet, Rey 2016.

4 For a useful theoretical-methodological perspective on the profound relativity of historical knowledge-a historian's attempt at reconstructing the past is not about the "historical facts", but about her/his conceptualization of the objects of his research, we refer to Otto G. Oexle's theory of Problemgeschichte: Oexle 2001.

5 The Cumont-Loisy correspondence is kept at the Bibliothèque nationale de France. Letters of Cumont to Loisy: ms. NAF 15651, fo 64-442; Loisy to Cumont: ms. NAF 15644, fo 55-329. Nine letters of Loisy are kept in the Academia Belgica in Rome. The correspondence will be published by A. Lannoy, C. Bonnet and D. Praet in 2018 (Mémoires de l'Académie des Inscriptions et Belles-Lettres). For a concise presentation: Lannoy 2011. 
comes the true object of religion. Christianity, in Comte's positivistic philosophy of history of religion, is not the final stage of development. The final stage, or l'état positif, is the phase of the truly universal religion de l'humanité. Paradoxically, we especially come to understand how profoundly Cumont's and Loisy's historiographies on the mystery cults were structured by similar evolutionary ideas from the letters that questioned the validity of the religion de l'humanité. Cumont and Loisy wrote each other from 1909 until 1940, a considerable period of time which included several of the darkest episodes in $20^{\text {th }}$ century European history. The traumatizing events of La Grande Guerre forced both scholars to question their firm belief in human progress. It will not come as a surprise that the religion de l'humanité mostly entered the foreground of their scholarly discussions during and after WWI. In this paper, substantial attention will go to the question as to what extent Loisy and Cumont revised their evolutionary frameworks during the Great War.

This paper intends to examine how Cumont and Loisy created their religions orientales (Cumont) and mystères païens (Loisy) as a group of religions with distinct social, religious and moral features, and with their very own position in the history of religions. Furthermore, it aims to demonstrate how deeply entangled their historiography was with their own worldviews. ${ }^{6}$ After a preliminary section which introduces their theoretical views on religion and the history of religions, we will first study their main publications on the subject: Cumont's Mystères de Mithra (1900) and Religions orientales dans le paganisme romain (1906) and Loisy's Mystères païens et le mystère chrétien (1913-1914). Special attention will go to the different compositional, narrative and terminological decisions they made and to the methodological reasons behind their divergences. In the final part of our paper, we will focus on the correspondence. Through the study of a selection of letters written during WWI, we hope to illuminate the complex historiographical interaction between studied past, lived present, and hopes for the future.

\section{Setting the frame for Cumont's and Loisy's historiography of religion(s): What is religion? What is the history of religion(s)?}

Modern scholarship on Cumont has conclusively shown that he was reluctant to theorize historical data. ${ }^{7}$ Cumont refrained from following the new sociological methods, and in his correspondence to Loisy he included a humoristic, yet rather condescending

6 For the interrelation of historiography on the mystery cults and the specific religious worldviews of the scholars who studied them, cf. the seminal study by Auffarth 2006, and the contributions to Lannoy, Praet 2018.

7 Cumont's friend Mikhail I. Rostovtzeff adopted the same attitude in the field of economic history: Bruhns 2005. 
note on the Durkheim school. ${ }^{8}$ Cumont consistently studied religions in their specific historical context and paid great attention to the nature, the origin and the orientation of the available evidence. He preferred to focus on the specific working of religions. As a result, one can hardly find any theoretical discussion of the concept 'religion' in his publications. The correspondence fills this void. It was Loisy's interest in finding the definition of religion which incited Cumont to tackle the problem. Let us begin with Cumont's letter of February 9, 1911. Cumont had read Loisy's new volume À propos d'histoire des religions (1911), in which the recently excommunicated priest and now professor of history of religions at the Collège de France gave a precious account of his personal conception of religion. Loisy formulated his ideas in reply to Salomon Reinach's Orpheus. Histoire générale des religions (1909). ${ }^{9}$ This French rationalist scholar had defined religion as 'un ensemble de scrupules qui font obstacle au libre exercice de nos facultés' (Reinach 1909, 4). A fierce polemic followed between them, and Cumont finally joined the discussion by writing to Loisy:

Vous avez bien raison d'insister dans votre préface sur la difficulté qu'on éprouve à définir la religion. J'avais songé autrefois à y voir 'tout ce que produit en l'homme l'idée du mystère qui l'environne' mais je me suis aperçu que cette phrase si vague était encore inadéquate. En réalité nous entendons par 'religion' des choses si différentes qu'elles en sont presque contradictoires. ${ }^{10}$

It is significant that Cumont here associates religion with 'mystery' and that his definition insists on religion being an individual experience. His definition, which he dismissed as insufficient, seems to announce Rudolf Otto's Das Heilige (1917), ${ }^{11}$ in which the numinous is explained as a non-rational and non-sensorial experience, 'terrifying' ('tremendum') and 'fascinating' ('fascinans') at the same time, defined as a 'mystery' ('mysterium'), a 'completely different' ('ganz andere') reality. As a student Cumont had been deeply submerged in the German Altertumswissenschaft (Bonnet 2005, and infra). So, at the time when he conceived of this definition ('autrefois'), he could easily have been influenced by a context which emphasized the importance of mystery, mysticism and, more generally, spirituality in religion (Krech 2002, 265).

Although we cannot go into detail about the concrete modifications, it is important to emphasize that Cumont's ideas on the position of religion in history underwent substantial changes over the course of his long career. And the same is undoubtedly true for his underpinning personal religious views, about which very little is known. Recent scholarship by Danny Praet on Cumont's philosophy of histo-

8 Cumont's letter to Loisy of July 13, 1911 (BnF, fo 106): 'Mon cher ami, Merci de vos bons souhaits mais gardez-vous d'abandonner votre chaire et surtout de mourir, vous seriez remplacé par quelque sociologue fumeux qui n'enseignerait plus l'histoire des religions parce qu'il n'aurait même pas l'idée de ce qu'on entend par "histoire".' On the intellectual context, Laplanche 1999.

9 For the debate Loisy-Reinach: Laplanche 2006, 87-88; Talar 2017. Cumont and Reinach also wrote each other, and discussed the definition of religion: cf. Lavagne 2000.

10 Cumont to Loisy, February 9, 1911, BnF, NAF 15651, fo 93.

11 Otto 1917. On Otto 1917: Melissa 1997; Gooch 2000; Matern, Dietz, 2012. 
ry suggests that the young positivist Cumont who wrote Les religions orientales dans le paganisme romain in 1905, regarded Christian religion as a phase in the historical development of mankind, which would eventually be superseded by a meta-religious humanism. ${ }^{12}$ In the 1930s, on the other hand, we see a more mystic Cumont, for whom religion seems to be an essential, yet invisible, motor of history. In his inaugural speech of the sixth International Congress of the History of Religions held in Brussels in 1935-one of the rare texts in which he expresses an opinion on 'what is religion?', he writes that it represents 'ces forces spirituelles qui ont métamorphosé des peuples et renversé des empires, comme l'effort invisible du vent fait ployer et déracine les forêts' (Cumont 1935, 294).

As for the religious history of Antiquity, Cumont is primarily interested in the mutations that affected the Roman Empire and his reflections focus on the specific role of the 'religions orientales' as the driving force behind the moral and spiritual changes of that epoch. All individuals could succumb to the appeal of the 'religions orientales', they fulfilled both the ritualistic needs of the lower classes and the spiritual and philosophical needs of the intellectual elites.

Loisy's intellectual project and scientific-religious background are substantially different from Cumont's. ${ }^{13}$ In his comparative study of sacrifice, which was his main research focus during his career as a historian of religions at the Collège de France, Loisy also expresses doubts on the theorizing, non-historicist approach to religion, as propagated by Mauss and Hubert. ${ }^{14}$ Yet, overall, he takes more interest in theories of religion than Cumont. Through his historical studies of sacrifice, Loisy eventually wants to proceed to general conclusions about the core of religion. As for Loisy's definition of religion and his history of religions, we again need to limit ourselves to some general remarks, all the while emphasizing that his views were subject to substantial changes in the course of time. In his book La Religion, published in 1917, Loisy defined religion as follows: 'En son idée la plus générale, la religion est le rapport spécial où l'homme croit se trouver et se met à l'égard des êtres ou des principes supérieures dont il s'estime dépendant, rapport qui s'affirme et se réalise principalement dans ce qu'on appelle le culte.' A notable point of difference with Cumont's def-

12 Praet 2015, LIV: '... son système dialectique de l'histoire le [Cumont] le conduisit même à dire que la thèse du christianisme et l'antithèse des Lumières et du Positivisme mèneraient à une ultime synthèse méta-positiviste et méta-religieuse.'

13 Lannoy 2012; Jones 1983; Laplanche, Biagioli, Langlois, 2007; Amsler 2013. Loisy’s intellectual evolution will be the subject of a monograph, currently in preparation, by Annelies Lannoy, 'I am the Einstein of the History of Religions'. Alfred Loisy and the making of history of religions in France (planned for 2018).

14 Our paper exclusively focuses on Loisy's secular career as a historian of religions at the Collège de France, which started in 1909. It was during this second career that he developed his ideas on the 'Christian Mystery.' Alfred Loisy is, however, best known as the pivotal figure of the Modernist crisis in the Catholic Church. In 1908, he was excommunicated because of his critical scholarship on early Christianity and ancient Judaism. For the comparative research he conducted during his Catholic career, cf. Lannoy 2018. For a general survey of Loisy’s anti-theoretical position: Strenski 2003, 197. 
inition is the focus on cult, which he evaluates positively because it reinforces cohesion in religious communities ('Ce n'est point à l'homme isolé que la religion s'adresse', Loisy 1917, 56). Loisy regards the history of religions as the progressive realization of moral and spiritual perfection, through the collective effort of engaged individuals. His supra-individualist definition of religion is different from Cumont's, although Loisy is firmly opposed against an exclusively sociological approach to religion. Both in his historical and philosophical publications, he points to the role of powerful individuals, and individual moral responsibility is a condition sine qua non for religious progress.

For Loisy, morality, spirituality and religion cannot be separated. Morality is based upon an inner spiritual force in man (Loisy 1917, 41). Moral progress is religious progress, and vice versa. During his time in the Church and perhaps still during his first years as an independent historian of religions at the Collège de France, Loisy considered Christianity as the final outcome of the history of religions. We will see that his ideas gradually changed: as Loisy progressively emancipates from his Catholic past, he becomes more and more convinced that Christianity should finally be replaced by a religion de l'humanité, a secular form of spirituality, which will establish a truly universal human solidarity.

Cumont and Loisy both adopt a historicizing approach to religion, and claim to favor a strictly empirical methodology. At the same time, they both frame their historical studies on the pagan mystery cults in an evolutionary philosophy of history. They impose a typological compartmentalization on the history of religions, by which they try to organize and classify religions according to the scientific standards of the natural sciences. Their work on the religions orientales and the mystères païens is implicitly and explicitly embedded in an all-encompassing historical narrative, which takes its departure in the prehistoric past, i.e. at 'the origins of religion', prefiguring all future developments of mankind. To enhance our understanding of their intellectual background, we will now briefly discuss (1) the idea of religious evolution in the longue durée; (2) the contemporary typology of religion; (3) comparison as an epistemological tool for the study of religions.

\subsection{Religious evolution in the longue durée}

Progress is the key to Cumont's and Loisy's conception of history. Applied to religion, it means that 'primitive' forms of cult and beliefs (e.g. animism or fetishism) yielded to more elaborate religious systems. Polytheisms with their local, then national organization are followed by monotheisms. In his inaugural lecture at the Collège de France, Loisy affirmed (Loisy 1909, 25):

À travers les mythes imaginaires, les cultes bizarres, grossiers, souvent cruels, derrière le fanatisme ardent des religions qui grandissent, la puissance d'inertie de celles qu'a figées une 
tradition immobile (...), il faut savoir, encore et toujours, discerner l'aspiration de l'humanité vers un idéal, vaguement perçu et voulu, de société bonne et de conscience satisfaite.

Accordingly, the final victory of Christianity over paganism in Antiquity is regarded as the 'aboutissement' of a long process of religious refinement. Its morality and universality are the two main reasons for its presumed superiority over preceding stages. This interpretation is not only inspired by evolutionary thought, but also by a colonial and Eurocentric perspective: history moves from the periphery to the centre, from the Orient and from Africa to Europe, from paganism to Christianity. Still, Cumont and Loisy are well-aware that the historical evidence on ancient religions and the elements observed in religions of their own time reveal a much higher historical complexity with overlaps, phenomena of persistence, resistance or resilience, and 'syncretisms', a concept often associated with Cumont's work. In his Religions orientales dans le paganisme romain ${ }^{15}$ (2006, 298), notably in the final chapter where he summarizes the religious mutations in the Empire, we find the following, fascinating passage on religious inconsistency:

Supposons que l'Europe moderne ait vu les fidèles déserter les églises chrétiennes pour adorer Allah ou Brahma, suivre les préceptes de Confucius ou de Bouddha, adopter les maximes du shinto; représentons-nous une grande confusion de toutes les races du monde, où des mollahs arabes, des lettrés chinois, des bonzes japonais, des lamas tibétains, des pandits hindous prêcheraient à la fois le fatalisme et la prédestination, le culte des ancêtres et le dévouement au souverain divinisé, le pessimisme et la délivrance par l'anéantissement, où tous ces prêtres élèveraient dans nos cités des temples d'une architecture exotique et y célébreraient leurs rites disparates; ce rêve, que l'avenir réalisera peut-être, nous offrirait une image assez exacte de l'incohérence religieuse où se débattait l'ancien monde avant Constantin. ${ }^{16}$

This inconsistency precedes Constantin's reign and the rise of Christianity, which brings order to the chaos! That is to say, Christianity settles the religious affairs of Antiquity, because Cumont and Loisy both asserted that Christianity, too, eventually fragmentized. Both scholars believed that the different Christianities (with their divergent denominational and national features) could not satisfy the pressing need for a truly universal humanism in their own early $20^{\text {th }}$ century reality. Christianity was the final step of the religious evolutions of Antiquity, but not of the history of religions tout court.

15 For more information on the re-editions of Cumont's work in the Bibliotheca Cumontiana: cf. the website of the Academia Belgica (www.academiabelgica.it), Brepols (http://www.brepols.net/Pages/ BrowseBySeries.aspx?TreeSeries=BICUMA), as well as the website on the Scripta Minora series: http://www.cumont.ugent.be/nl/publicaties.

16 For Loisy's awareness of the complexity offered by history: Loisy 1919, 19-20. 23. For Cumont's: Cumont 2006, particularly his Préface, 6-14, and chapter VIII, La transformation du paganisme romain, $298-314$. 


\subsection{Religious typologies linked to the different steps of evolution}

In the positivist intellectual climate of the $19^{\text {th }}$ and the early $20^{\text {th }}$ century, it was almost natural for scholars to organize knowledge in typologies. ${ }^{17}$ In order to study religions in a scientific, non-biased way, historians of religions rationally classified religions in different categories, which supposedly correspond to evolutionary stages in the history of mankind. To take the example of Loisy, his evolutionary framework consisted of three types or phases (Loisy 1919, 7sq.). The first type was the primitive cults with their magical approach to impersonal divine spirits and with moral obligations concerning only the tribe itself. In a second phase, nations emerge from the association of tribes. They venerate national gods, associated with a specific territory, and anthropomorphism makes its appearance. Moral obligations now concern a broader community, but they do not yet convey individual moral elevation (Loisy 1919, 11). The third step is the development of économies de salut within national religions. They address the individual who chooses freely, independently from his 'national' identity, to become an initiate. The promise of salvation incites any individual, all over the world, to grow morally and spiritually.

According to these views, the history of religions is equivalent to the history of the progress of the human species. In a letter to Cumont of 1920, Loisy discussed the publication of his volume L'essai historique sur le sacrifice (1920): 'Je crois que ce livre peut donner une idée assez juste de notre espèce et de son évolution, non seulement religieuse mais mentale, et morale, et sociale. Il me semble aussi que l'histoire du sacrifice, depuis les rites des sauvages jusqu'à la messe, y est rendue suffisamment intelligible. ${ }^{18}$ The uniformity of mankind, advocated by anthropologists like Edward Burnett Tylor $(1874,6)$, guarantees the universal validity of the evolutionary framework.

\subsection{Comparativism as an epistemological tool for the history of religions}

Colonialism significantly accelerated the rise of comparative religion. Anthropologists like E.B. Tylor believed that one could easily have access to the first steps of the religious evolution through the observation of the 'primitive' tribes, outside of the European continent (Tylor 1874, 71). History was brought back to life by modern ethnography. The popularity of comparative religion significantly increased in the last decades of the $19^{\text {th }}$ century and in the first half of the $20^{\text {th }}$ (Laplanche 1999; Sharpe 1994). But there was no agreement whatsoever about the newly developed

17 See, e.g., the model of Cornelis Petrus Tiele (1830 -1902) in his Outlines of the history of religion to the spread of the universal religions (1877) or Elements of the science of religion (1897-99), cf. Sand 1999, 117.

18 Loisy to Cumont, July 8, 1920, Academia Belgica, cote 6509. 
comparative methods among historians of religions. Jules Toutain, who was one of Loisy's rivals for his chair at the Collège, was very sceptic about comparative methodology, even though he had translated Frazer's Golden Bough into French. According to the exponents of the traditional historical method, who often followed a nationalist approach (History of France, of Germany, of England...), comparativism would eventually lead to excessive generalization.

Moreover, whereas comparing the Greeks with the Iroquois was almost acceptable for everybody, comparing Christianity with other religions was a much more delicate and risky matter. Many traditional Christian scholars (both Catholics and Protestants), considered Christianity as something else, to be placed above comparison and historicization. ${ }^{19}$ Both Cumont and Loisy personally suffered from having taken the risk of studying Christianity as a religion among others (cf. infra).

\section{The historiographical construction of the religion orientales and the mystères païens: a study of Cumont's and Loisy's published work}

Cumont and Loisy used the concepts religions orientales and mystères païens to describe and to analyze what they considered an epochal turn in the religious development of mankind. These religions represented a crucial step in the direction of higher morality, spirituality and universality, in contrast to the excessively mundane and 'nationalist' traditional pagan cults. The mystery cults are the missing link between 'traditional' paganism and Christianity.

\subsection{Franz Cumont}

In 1905 Franz Cumont was 37 years old. Eleven years earlier, he had begun to publish his impressive volumes on Mithras: Textes et monuments figurés relatifs aux mystères de Mithra (1894-99). ${ }^{20}$ Shortly after finishing his academic education, which he had started in Belgium and continued in Germany with Usener and Diels, and later in Paris with Duchesne (Bonnet 2005), Cumont was already considered a leading scholar in his field. His scientific network grew impressively at the beginning of the $20^{\text {th }}$ century and his interest in ancient religions focused on the transition between paganism and Christianity. Partisan of a liberal ideology, Cumont was fascinated by the progressive emancipation of the human mind in Antiquity, from the grip of

19 For more information about the different positions in these debates: Lannoy, Praet 2018; Lannoy 2012, 145-236; Smith 1990.

20 See also the recent edition of Les Mystères de Mithra (the book with the conclusions of TMMM): Cumont $2013\left(1900^{1}\right)$. On Cumont and Mithras, cf. the Introduction in Cumont 2013, XIII-XC. 
magic to a spiritual elevation. In a letter to Hermann Usener of 1900, he announced that he intended to write the history of the end of paganism, 'if it ever came to an end. ${ }^{21}$ Since Cumont believed that there was no clear-cut boundary between paganism and Christianity, he needed new tools to understand the 'middle ground' between them. This was his major intellectual challenge.

The study of Mithras incited Cumont to develop a new conception of religious dynamics in the Roman Empire. Whereas many scholars before him-for example Renan (Renan 1882)-believed that the (old and pure) Roman religion got corrupted by the many different cults practiced on imperial territory, Cumont developed a more nuanced view on the role of foreign cults (Praet 2014). According to Cumont, Mithraism was deeply permeated by the Persian-Mazdean dualistic conception of the cosmos: the victory of good over evil, of light over darkness, of morality over corruption. The cult involved various degrees of initiation along which the soul of the initiates could come to progressive elevation. Mithra's diffusion favored the emergence of new religious standards, which brought about the weakening of traditional Roman cults (too 'cold' and 'mechanical') and prepared the coming of Christianity. From the Orient-ex Oriente lux!-new religious input arrived in the Occident, with both positive and negative effects on the religious landscape of the Roman world. ${ }^{22} \mathrm{Be}$ cause of their exotic appeal and higher morality, the 'oriental religions' spread widely and even seduced the emperors and their family. Cumont implicitly suggests that Judaism and Christianity were part of that historical movement, from East to West, from polytheism to monotheism, from syncretism to henotheism, from ritualism to the inner sanctuary of individual morality.

In 1905, Cumont was invited to give the prestigious Michonis Conferences at the Collège de France (Rey 2010). While he had earlier focused on Mithras, his historical studies now encompassed all religions orientales from the Eastern part of the Empire. The results of his lectures are published in Les religions orientales dans le paganisme romain (1906), a very successful and influential book, which was republished several times and translated in English (American), German and Italian (Bonnet, Van Haeperen 2006, xi-lxxiv). One can hardly overestimate the impact of Cumont's book in the following decades. A recent study of its reception (Van Haeperen 2007) has shown that it mobilized both historians and theologians throughout Europe and fueled fiery debates on the comparability of Christianity. The book, together with his work on Mithras (TMMM and Les Mystères de Mithra), would have far-reaching consequences for Cumont's professional life some years later $(1910-11) .^{23}$

Before we take a closer look at the narrative structure of Cumont's book, it is crucial to point out that it was written for a large readership. Its particular narrative style is probably to be explained by its specific origin, although it also characterizes many

21 Letter of F. Cumont to H. Usener of 11 III 1900, published in Bonnet, 2005, II, 200 n $^{\circ} 20$.

22 On Cumont's orientalist ideas: Scheerlinck 2014 and Scheerlinck, Praet, Rey 2016.

23 On the affaire Cumont: Bonnet 1997, 495-512; Praet, Bonnet 2018. 
other writings of Cumont. Even if Cumont's scientific prose differed from the Romantic pompous style, it is indeed often lyrical and poetic. History consists in a literary account, and Cumont's narrative is extremely cohesive and rich. The empirical foundation of the volume displays an incredible amount of data from ancient texts, inscriptions and images.

Cumont opted for a geographic order. After two introductory chapters on the sources to study the relationship between Rome and the East, and on the conditions and the agents of the diffusion of the 'Oriental religions', he dedicated four chapters to four different regions: Asia Minor, Egypt, Syria and Persia. This way he reinforced the idea of a diffusion of religions catching the West and Rome in their grip. In the wake of Juvenal, Cumont describes a religious flood which progressively overflows. ${ }^{24}$ This process is at the same time responsible for the 'destruction' of the old national fossilized Roman religion, and for the emergence of a new religious framework. The diffusionist matrix of the book is deeply embedded in its evolutionary framework. From each province of the Eastern part of the Empire runs a specific religious current and all these currents meet in Rome, where all 'religions' finally give birth to one 'religion' with Constantine. Each 'Oriental religion' provides a specific contribution to this general movement, even if they are imperfect and include crude ritualism, magic, exoticism, and even orgiastic cults.

The different 'Oriental religions' are presented as 'congregations' or 'sects' of a common church. Despite their differences and peculiarities, they share a set of common features: eccentric and exotic ritualism, on the one hand, which make them particularly attractive to the most humble, and their focus on personal salvation, on the other hand, which seduced the intellectuals and the political elites. Through their mystic doctrines and through specific mystery rituals, Isis, Mithras or Cybele elevated the soul and stimulated empathy between men and the divine. They e.g. associate their mystery rituals with particular mythical accounts expressed by distinctive images, but, in the end, they share a 'doctrinal' heritage and produce a common sense of belonging. The 'Oriental religions', Cumont argued, all propagated the idea of astral immortality. The fact that these religions were imbued with astrological lore makes them particularly appealing to the intellectual elites who were attracted by the (pseudo-) scientific content of these religions (Praet 2015; 2016). Furthermore, by calling them 'religions', Cumont shows that he considers them as social entities with their own dynamic and with a particular impact on the general religious evolution. He identifies them as the agents of a 'moral revolution', as a new religious model which is the key to a social progress towards spirituality and universality.

Cumont concludes his geographic exposition with two more synthetic chapters which further develop his evolutionary views: the first one (chapter VII) addresses the tricky question of astrology and magic, while the second one (chapter VIII) ana-

24 Juvenal, Satire III, 60 - 66: 'iam pridem Syrus in Tiberim defluxit Orontes.' Cf. Bonnet, Van Haeperen 2006, xxxviii. See also Belayche 2000. 
lyzes the transformations Roman paganism underwent in the new religious landscape. If the 'Oriental religions' set new religious standards based on morality and spirituality, how is it possible that astrology and magic played such an important role in their doctrine? The answer to this question is difficult to gauge. In se astrology and magic are strongly depreciated: Cumont qualified them as chimera or mirages, as fake knowledge. Nonetheless, they do contribute to the emergence of a new theology which centers on the tight link between the individual human fate and his environment. Magic and astrology underline the analogy between man and the cosmos. Magic prefigures physics, and astrology announces astronomy. ${ }^{25}$ The experimental observations of the Chaldean magoi, though often ridiculous and superstitious, played a part in the emergence of a higher awareness of the universal divine powers which orchestrate the cosmic machine. ${ }^{26}$

In his final chapter Cumont opted for the singular: 'La transformation du paganisme'. One transformation and one Paganism. The rich diversity of cults from Syria, Persia, Anatolia, Egypt... finally converge in one big movement. At the very beginning of this chapter we read (Cumont 2006, 297): 'La religion de l'Europe vers l'époque des Sévères devait offrir à l'observateur un spectacle d'une étonnante variété. (...) Cent courants divers entraînaient les esprits, ballottés et perplexes; cent prédications contraires sollicitaient les consciences.' But who are the agents of this transformation? If the core of the 'Oriental religions' was primitive and rough, the priests managed to polish it. The ancient 'barbarian' traditions transformed into refined ideals of spiritual purification and moral elevation, with sophisticated conceptions of the cosmic divine. In Cumont's narrative, as Annelies Lannoy has demonstrated for Lux Perpetua (Lannoy 2010), different social groups are taken into consideration: the masses, with primitive rituals and beliefs which are slow to change, and the sacerdotal and intellectuals elites, who are innovative and mobile, and adopt the role of religious 'passeurs' between East and West. Thanks to their permeability to Greek philosophy and

25 For a comprehensive analysis of Cumont's views on the role of astrology in the ancient history of religions, cf. Praet 2015, in which an important, unknown text of Cumont Le problème de l'astrologie (1911, reprinted in Cumont 2015) is investigated.

26 For the relationship between science and religion in Cumont's thought, we refer to the recent analyses of Danny Praet (2015; 2016), who has shown that Cumont's philosophy of history described a progressive distinction between religious and scientific worldviews. Praet demonstrates that the overall structure of Cumont's Religions orientales was ideologically motivated. The order of the four 'geographical' chapters, followed by the chapter on astrology and magic-which are indeed 'hardly Religions and not specifically Oriental' (Praet 2018), was symbolic: the chapters are structured along an upwards scale of morality, spirituality, personal freedom and a (pseudo-)scientific contemplation of reality. The least civilized and rude cult of Cybele is discussed first, while Mithras-with its higher morality and astral theology-represents a higher phase of development. Magic and astrology, as attempts at science, are crucial for the realization of the Comtian 'metaphysical' stage, and, ultimately, heralds of the scientific stage. Praet also analyzes the highly dialectic Hegelian thought which underpins Cumont's views on the gradual distinction of religion, science and politics in history (cf. especially Praet 2015, LII sq.). 
to their role in the imperial courts, they have prepared the path for the coming of monotheism (Cumont 2006, 305):

Dans le péril commun qui les menace, les cultes autrefois rivaux se sont réconciliés et se regardent comme des divisions d'une même église, dont leurs clergés forment, si j'ose dire, les congrégations. Chacun d'eux est consacré particulièrement à l'un des éléments dont la combinaison forme l'univers; leur ensemble constitue la religion panthéiste du monde divinisé.

Cumont deliberately uses a Christian vocabulary in order to draw a parallel between the 'Oriental religions' and Christianity. Through his lexicon, he suggests the idea of continuity between them. His stylistic devices suggest that the transition is 'natural' since the 'Oriental cults' are already congregations with a church and a clergy. But, on the other hand, the church which results from the union of the different Oriental cults is quite dissimilar from Christianity. There is no personalized God, but the universe, the cosmos, with its metaphysic dimension. Cumont seems to jump from Mithras to the 'Great Clockmaker', ignoring the Christian God. Christianity was the final stage of the history of religions of Antiquity, but in Cumont's overall history of religion it was certainly not (see also Praet 2012, 208 sq.). The very last sentence of his book is (Cumont 2006, 314): 'L'esprit religieux et mystique de l'Orient s'était peu à peu imposé à la société entière, et il avait préparé tous les peuples à se réunir dans le sein d'une Église universelle.' There will be 'one universal Church', and not explicitly or necessarily the Christian one. It is precisely in this part of the book that Cumont mentions Auguste Comte and his model of a religious evolution linked to the progress of science, knowledge and consciousness. ${ }^{27}$ According to Cumont (2006, 306-7), with the diffusion of the Oriental mystery cults,

la croyance n'est plus instinctive et impulsive; l'érudition et la réflexion ont reconstitué toute la théologie. En un certain sens, on peut dire que celle-ci, selon la formule de Comte, a passé de l'état fictif à l'état métaphysique. Elle est étroitement unie à la science du temps, que ses derniers fidèles cultivent avec amour et avec orgueil, en héritiers fidèles de l'antique sagesse de l'Orient et de la Grèce. Elle n'est souvent qu'une forme religieuse de la cosmologie de l'époque c'est à la fois sa force et sa faiblesse - et les principes rigoureux de l'astrologie déterminent la conception qu'elle se fait du ciel et de la terre. L'univers est un organisme qu'anime un Dieu unique, éternel, tout-puissant.

Cumont is fascinated by the anthropology that underpins such a religious system or philosophy (2006, 311): 'Suivant un symbole généralement accepté, l'esprit qui nous anime est une étincelle détachée des feux qui resplendissent dans l'éther; il participe à leur divinité et il est, croit-on, descendu sur la terre pour y subir une épreuve. On peut dire à la lettre que "L'homme est un dieu tombé qui se souvient des cieux".' Man is

27 It should be underlined here that Cumont's own religious views remain very difficult to gauge, due to the overall lack of explicit autobiographical information on this aspect of his thought. Cf. supra, note 13 for the younger Cumont, and the same page for the substantial changes Cumont's thought certainly underwent in the course of time. 
part of the cosmos, thus part of the divine. Any knowledge, any science gives man the keys to that elevation. Christianity, to be sure, is an important stage in the religious evolution, because it conveys a universal conception of god and mankind (in contrast to the entirely mythical and locally venerated pagan gods), but it is not the last stage in as much as Christianity is historically born from Hebraism and Judaism, and through them still has national 'roots' (Praet 2018). Although Judaism is monotheistic, it remains a national religion, like Greek or Roman polytheism. In Cumont's view, only a Comtian post-Christian religion de l'humanité will offer a fully human and therefore truly universal perspective. ${ }^{28}$ However, Judaism did play a special role in Cumont's historical scenario. Small groups of Jews established in different Eastern areas, such as Egypt and Anatolia, favored encounters between Judaism and local, 'weaker' cults, such the Phrygian-Thracian Sabazius, who underwent Judaic influence (Lannoy 2012, 462-471; Praet 2013 for Cybele). Judaism contributed to the emergence of Judeo-syncretistic cults, which began to mix polytheism and monotheism, Paganism and Judaism, thus announcing the Christian synthesis.

To conclude, we would like to stress the fact that, in spite of Cumont's claims of empirical objectivity, the ideological framework displayed in his publications is evidently shaped by his personal itinerary (Bonnet 2010)-a Christian education given by his mother, the influence of the liberal convictions of his father -, by his professional network, in which Loisy has an important position, by the intellectual trends and scientific debates of his time, and last but not least by the tragic events his generation has to face. We will return to the impact of WWI in the final part of our paper, but let us first look at Loisy's mystères.

\subsection{Alfred Loisy}

Other than Cumont for whom the 'religions orientales' were a subject of fascination from the very start of his scientific career, Loisy only began to actively study the mystères after his appointment to the chair of history of religions at the Collège de France. Comparative research on pagan religions and Early Christianity was, as has been mentioned before, a dangerous subject of research for scholars in- and outside the Church. The evolutionary philosophy of history, however, in which Loisy was going to frame his study of these cults, was far from new. Ever since the 1890s, he had embraced a profoundly evolutionary conception of history, which was one of the main reasons for his later excommunication in 1908 (Lannoy 2018). The differences between Modernist and 'post-Modernist' Loisy should in this respect certainly not be overemphasized.

28 For Cumont's knowledge of Comte and Cumont's original position towards the Comtian framework, cf. Praet 2015; 2017. 
The best source to study Loisy's mystères, is his book Les mystères païens et le mystère chrétien (published in 1919, written between 1913-14, henceforth $M P M C$ ), ${ }^{29}$ which was in fact the sole monograph he dedicated to the subject. Before turning to an analysis of Loisy's historiographical constructions, it may be useful to briefly discuss the guiding principles, the aims, and the conclusions of Loisy's work. ${ }^{30}$ As mentioned before, Loisy and Cumont studied pagan mystery cults from quite different perspectives: Loisy's was a comparative study of sacrifice, which induced him to not just study the 'oriental' mysteries, but also Dionysos and Eleusis. ${ }^{31}$ Contrary to Cumont, he did not adopt a diffusionist approach with the Orient sweeping over and transforming the Occident. His principal aim is to show that the 'pagan mysteries' and the 'Christian mystery' represent the same type of religion, i.e. the trans-cultural économie de salut category, with its distinct features (i.e. their particular sacrifice). ${ }^{32}$

Loisy's MPMC is built on two comparative principles (Loisy 1919, 9-24). The first is the afore-mentioned conviction that the history of religions runs along a universal three-phased scheme of development: primitive cults-national religions-économies de salut. The salvation religions all develop within the national religions, yet, at a certain point in time, they denationalize and become universal religions, addressing the personal spirituality and morality of each religious individual in the world, instead of that of the nation. The second axiom is the ritual-myth theory which was essential to all his studies of sacrifice (Loisy 1919, 20). Ritual always precedes myth, and myth is a rationalization which provides the ritual with new meaning, when its original significance has been forgotten, or needs reformulation. For Loisy, religion is ritual, and myth is a product of religion (Loisy 1909, 30).

Loisy systematically applies these two axioms to the pagan mysteries and to the Christian mystery. All mysteries have similarly developed from a national religion: for Mithras this is ancient Persian religion, for Cybele and Attis the religion of Pessinus, etc., and for Christianity the national ancestor is Judaism. Secondly, all mysteries have similar rites de salut and mythes de salut, which are different from national counterparts because of their highly mystical and spiritual content. The most important rites are the sacrificial meals. By eating the victim-which is assimilated to the mystery god-the initiate enters into a mystic union with the savior god and takes part in his immortality. All mystery rituals are believed to be a figuration of the vicissitudes (the 'passion') of the mystery god, who is always a self-sacrificing dying and resurrecting figure.

29 The book is a compilation of a series of articles of 1913-1914. It was published with a substantial delay due to WWI.

30 For an in-depth analysis of Loisy's comparativism in MPMC: Praet, Lannoy 2017.

31 Dionysos was only added by Cumont in the $4^{\text {th }}$ edition of $R O$, and Eleusis fell-for evident reasons -out of the scope.

32 For a historical study of the emergence of the concept of universal 'World Religions' in European science of religion, cf. Masuzawa 2005 (especially chapters 7, 8, and 9). 
For Christianity, Loisy came to the following conclusions. Jesus was not the founder of a new religion: Jesus was a Jew and his gospel of the imminent Kingdom of God was Jewish. He did not institute Christian rituals, but followed Judaic Law. After Jesus died, his disciples 'corrected' his death, by their belief in his resurrection. They started to attach special importance to celebrating meals in remembrance of those they used to have with him. It was Paul who finally transformed the still Jewish 'sect' into an autonomous and universal religion after the model of the pagan mysteries. He developed the mystery myth of the self-sacrificing Christ who died to redeem mankind, and turned the ritualized meals into a true mystery ritual. A similar process took place for baptism, though this was a ritual from the very beginning: a Jewish purification ritual which was reinterpreted as an initiation ritual representing the death and rebirth of Christ. To account for the far-reaching similarities of the pagan mysteries and Early Christianity, Loisy combined an anthropological model of universal analogy with a genealogical explanation (Praet, Lannoy 2017). People like Paul were acquainted with the pagan mystery cults because they were part of their religious environment. ${ }^{33}$ They used this knowledge to transform Jesus' gospel into a universal mystery.

MPMC consists of 10 chapters. The first chapter unfolds the guiding principles of the book and is the cement between the following, seemingly independent chapters II to VI, dedicated to the pagan mysteries: II. 'Dionysos et Orphée'; III. 'Les mystères d'Éleusis'; IV. 'Cybèle et Attis'; V. 'Isis et Osiris'; VI. 'Mithra'. Chapters VII to X discuss the development of the Christian Mystery: VII. 'L'Évangile de Jésus et le Christ ressuscité' relates the events during and immediately after Jesus' life; VIII. 'L'Évangile de Paul' focuses on the transformation of the resurrected Christ into a mythical savior god; IX. 'L'initiation chrétienne' discusses how Paul transformed the ritualized meals and the original purification rite into 'rites de salut', the Eucharist and baptism, by connecting them to his savior myth of Christ; chapter X deals with 'La conversion de Paul et la naissance du christianisme.'

The table of contents shows that Loisy dealt with the Christian mystery in far greater detail than with the pagan mysteries. This should not only be explained by Loisy's personal interest in Early Christianity. His predominant attention for Christianity is also related to the principal aim of the book, which was not to show that the pagan cults constituted one type (this had sufficiently been demonstrated by Cumont and Reitzenstein), but that the pagan mystery cults and Christianity were one type. That Christianity also was a mystery simply asked for more explanation. Loisy discussed the pagan mysteries in individual chapters ${ }^{34}$ rather than opting for a thematic approach, e.g. by individual chapters on 'the rituals' or on 'the myths' in which he could then discuss the similarities between different cults. To approach the mystery cults thematically (like Reitzenstein 1910 had done) might have suited his compara-

33 Loisy referred to the presence of Mithras in Tarsus, cf. Loisy 1919, 323.

34 Note, though, that he chose not to give the chapters geographic titles. 
tive project equally well, or perhaps even better, because it would have enabled Loisy to easily draw comparisons between them and to prove that these religions constituted a distinct type of religion. But, interestingly, Loisy hardly ever drew explicit comparisons between individual mysteries, and historical contacts between them are rarely mentioned, either (Praet, Lannoy 2017). The implications of his compositional decision are twofold. On the one hand, the discussion of the mysteries in separate chapters suggests that Loisy studied them inductively. It also invites the reader to look at these cults as autonomous cults or sets of related cults (e.g. Dionysism and Orphism). These historiographical choices may have been inspired by Cumont, whose work he knew particularly well. In each chapter (and in the Christian section) Loisy provided each mystery with an individual narrative of its history, and an account of its ritual and related myth. This particular composition of the book furthermore fitted in neatly with the analogical framework he used to account for the similarities between these religions: the historical development of each mystery, the process of transformation from primitive vegetative sacrifice to mystic 'communion' is narrated as an isolated, independent and spontaneous process.

Although the structure of the book suggests that Loisy will pay attention to the peculiarities of each mystery, his approach was actually very systematic and homogenizing, up to the point that he forced the historical evidence into the 'mystery' mold he had created. All pagan chapters include an introduction of their content and 'national' origin, a section devoted to the myth of the dying and resurrecting god (a pattern to which even Mithras is bound to correspond: Loisy 1919,191), and one or more sections devoted to the mystery rituals. These points are not always addressed in the same order, but they are always discussed in the same way. Adopting a Frazerian approach, Loisy explained the original meaning of all sacrificial rituals by referring to a dying and resurrecting spirit of nature, which later transforms into a transcendent personal god. The myth consistently spiritualizes and provides the ritual with a progressively mystical meaning. Although they all followed the ritual-myth principle, Loisy did acknowledge an important difference in the development of the pagan mysteries and of the Christian mystery: i.e. the fact that the Christ myth did not stem from a dying and resurrecting spirit of vegetation, but from the historical event of Jesus' death and its reinterpretation by his disciples.

There is a good chance that the order of the chapters is partially motivated by Loisy's personal evaluation of the mysteries: the chapters seem to have been arranged from 'lowest' to 'highest' mystery, or the most perfect realization of an économie de salut, based on their score on the parameters of universality, spirituality and morality. An additional criterion that matters to Loisy, is the extent to which they formed autonomous social entities (cf. infra). The first cult Dionysos et Orphée, though, is excluded from such hierarchizing order: for the mysteries of Dionysosof which Orphism was a particular form-Loisy explains why he discussed them before all other mysteries: i.e. they were the first who lost their importance in Roman 
paganism (Loisy 1919, 25). ${ }^{35}$ By demonstrating that the Christian mystery belonged to the same type of religion as the pagan mysteries, Loisy took a firm stand against Christianity's self-postulated uniqueness and originality. Still, from this strong scientific position-which had provoked his excommunication from the Church in 1908does not follow that Loisy considered Christianity as a mystery among others. For Loisy, the Christian mystery is the most perfect realization of the économie de salut category (Loisy 1919, 357-8). Loisy especially emphasizes the superiority of Jesus' historicity over the mythical pagan gods: man himself has now become god. The humanist turn of Christianity makes it a truly universal religion, capable of uniting mankind. Right before the Christian section, which represents the 'climax' of the book, comes the chapter on Mithraism. Loisy fully concurred with Cumont in considering Mithraism as the most moral, universal and socially organized of all pagan mysteries. ${ }^{36}$ Eleusis, on the other hand, was the first mystery Loisy discussed (NB after 'Dionysos et Orphée'). In his view, this mystery was the least universal, as it was controlled by Athens, and the least socially autonomous, because there was no such thing as an Eleusinian 'community'. As for the following chapters on the 'oriental' mysteries, Loisy followed the order of Cumont's religions orientales, which corresponded to a personal-ideological evaluation of these cults. The only difference with Cumont is the fact that Loisy didn't mention the Syrian religions orientales, possibly because he didn't consider them 'mysteries'.

Aside from the compositional tools, Loisy's terminology was also instrumental for the creation of the 'mysteries', as a type of religion and as individual religions (Lannoy 2012, 288-290). Contrary to Cumont's religions orientales, Loisy decides to use the word mystères. This was a conscious choice, because Loisy doesn't regard all mystères as religions. The term religion is not used in the chapters 'Dionysos \& Orphée' and 'Éleusis' and only rarely in 'Attis \& Cybèle' (Loisy 1919, 86, 100 -101). Here we only find the terms culte and mystère. For 'Osiris-Isis' and 'Mithras', on the other hand, Loisy uses both culte and religion. ${ }^{37}$ Loisy doesn't give an explanation for his terminology, but we have good reasons to assume that it was not entirely arbitrary. In the second edition of MPMC, Loisy added a significant sentence about Eleusis (1919, 82): 'Les mystères d'Éleusis ne furent pas une religion, comme l'étaient par exemple, ceux d'Isis et ceux de Mithra.' He motivated this statement in two ways. First of all, Eleusis initiates did not form a religious community, and we know that the social dimension of religion was tremendously important for Loisy. Secondly, salvation did not depend on personal morality, and for Loisy religion was morality. It is difficult to ascertain to what extent these qualifications can also explain Loisy's distinctive terminology for the other mysteries, but for one cult at least, it becomes absolutely

35 For recent scholarship on the pagan mystery cults we refer (among many other publications) to Auffarth 2013, Bremmer 2014 (cf. especially chapter 4, 'Greek Mysteries in Roman Times' and chapter 6, 'Did the mysteries influence Early Christianity?'), and Belayche, Massa 2016.

36 Unsurprisingly, Loisy believed that this mystery cult had the greatest importance for Paul. 37 In 'Osiris-Isis', culte is preferred to religion; in 'Mithras', religion is preferred over culte. 
clear why he uses the term religion: i.e. Mithraism, which Loisy considers to be the most moral cult and the most tightly woven community (followed by Isis). A third and last element that played a role for Loisy's use of the term was the extent to which the mystery had truly detached itself from its 'national' context and acquired universal aspirations. In this sense, too, Eleusis was not a fully developed 'mystery', because it did not 'travel' as the other mysteries did. This third element also helps us to understand the terminology in the 'Christian' chapters. Loisy avoids the term religion when writing about Jesus and his disciples. They are a secte or mouvement within Judaism, characterized by a Jewish gospel about the Kingdom and by Judaic law. When Paul developed the myth of the universal savior god and when he consolidated the rituals of the Eucharist and baptism by inventing the myth of the institution by Christ himself, Loisy prefers religion.

Before turning to the final section of our paper, we briefly want to point out that the chapters on the pagan mysteries rarely discuss the agents performing the religious transformations. Contrary to Cumont, Loisy pays little attention to the role of the priests and to the impact of these cults on individuals. Loisy's outlook is decisively supra-individual. The history of religions seems to be driven by some sort of anonymous force towards progress: religions evolve or die. This perspective is more than a narrative trick to circumvent the gaps left by meager historical evidence. It is a conscious choice that fits Loisy's theoretical framework of universal analogy.

By analyzing Loisy's book, we come to understand that at the time of writing (1913), he still considered Christianity as the most advanced économie de salut, and, apparently, as the final phase of the overall history of religions. But Loisy's emancipation from his Christian background was about to be brutally accelerated by WWI. The event had enormous consequences for his views on the history of religions, and this was not different for Cumont.

\section{Religion de l'humanité and World War I in the Cumont-Loisy correspondence}

In the first year of the War, the frequency of Cumont's and Loisy's correspondence dropped to an alarming depth. When the correspondence resumed in February 1915-after a long silence in the summer and the autumn of 1914-both friends drew a sigh of relief. From that moment onwards, scholarly discussions on the history of religions momentarily moved to the background of their letters and the War became the most prominent point of discussion. Loisy and Cumont were spared from the loss of close beloved ones, and, materially, the War did not affect them significantly, but, even so, the 'Grande Guerre' was an important turning point in their lives (Bonnet 2005, Talar 2015). In their letters, they discussed military actions (Loisy's residence in Ceffonds was right at the front), but they also wrote on the involvement of the Church in the War, and they talked-almost therapeutically one could 
say-about how profoundly the cruelties of all involved parties affected their belief in human progress and evolution. This is the moment when Cumont and Loisy openly discussed and questioned a positivist philosophy of history.

The correspondence contains an enormous amount of highly relevant letters which allow for a detailed analysis of the subtle differences between Cumont's and Loisy's post-War histories of religion(s). A similar comparative study of their letters falls outside the scope of our paper, but we do want to give our readers an idea of the complex interrelation of the scholars' own reality, their ideological views on the religion de l'humanité, and their reconstruction of the religious transformations of Antiquity. Rather than quoting shorter sentences from different letters, we will quote two larger passages from two significant letters and confine ourselves to minimalist comments.

\section{Letter 1: 'Vous supposez un homme qui au fond est bon'....}

The first letter was written by Cumont on April 29, 1917. The letter is mostly a reaction to Loisy's treatise La Religion (1917). In this petit livre rouge the French scholar systematically exposed his views on the nature, the history and the future of religion. To understand Cumont's letter, it is important to add that, in spite of the atrocities of the War, Loisy decided to stick to his belief in human progress through religion. La Religion included an adapted, but still very much positivist account of history of religion. The most substantial change, with regard to $M P M C$, was that Loisy no longer regarded Christianity as the final step of religious evolution. We will come back to this change of opinion when we discuss letter 2. According to Loisy's La Religion, the realization of a truly humanist, universal Religion de l'humanité was an infinite work in progress. Loisy's study of the history of religions revealed to him that it was a long process of refinement, in spite of occasional set-backs. Cumont, however, was not so sure about this: ${ }^{38}$

Paris, 29 Avril 1917

Mon cher ami,

J'ai bien tardé à vous remercier de votre nouvel envoi : je me suis réjoui du succès de « Mors et Vita ». Il égalera difficilement les mérites de votre opuscule et l'ineptie de Bourget. Le beau frontispice que vous avez ajouté à ce " tempietto » engagera les passants à y entrer et ils voudront monter de là au grand sanctuaire que vous avez bâti derrière ces propylées sur un rocher élevé. C'est après avoir fait moi-même cette ascension que j'ose enfin vous écrire. Dois-je vous dire que la « Religion » abonde en idées profondes et en vues étendues sur lesquelles il faut, bon gré mal gré, que la méditation s'arrête. Je me trompe fort, ou ce volume exercera une influence durable sur la pensée contemporaine, malgré le silence obstiné de ceux qui craignent sa diffusion. Il ne sera pas lu par le profanum vulgus et beaucoup d'esprits superficiels ou sceptiques s'arrêteront au premier chapitre. Comme lui et par une nécessité semblable, l'Éthique

38 Cumont to Loisy, April 29, 1917, NAF 15651, f²23-25. 
de Spinoza débute par les questions les plus abstraites de tout l'ouvrage, et celui-ci n'a jamais fait les délices des débardeurs d'Amsterdam, ce qui ne l'a pas empêché de faire son chemin dans le monde. Mais vous aideriez, je crois, à l'intelligence de votre livre, qui est solidement construit, par une table des matières, qui donnerait un résumé analytique des chapitres. Il faut toujours compter avec la bêtise et la paresse du public dit intelligent éclairé.

Ceux qui vous auront suivi jusqu'au bout, éprouveront souvent, je crois, le sentiment que vous avez exprimé fortement et formulé nettement ce qu'eux-mêmes pensaient ou plutôt sentaient confusément. Il est bien probable que nous allons vers quelque forme de religion de l'humanité, telle que vous l'esquissez en de fort belles pages, Vous avez admirablement montré tout ce qu'elle devra à un passé, qu'elle peut rejeter partiellement mais non abolir. Les antinomies de la foi traditionnelle et de la libre pensée se résoudront ainsi en une synthèse plus haute. Hegel vous eût approuvé. ${ }^{39}$ Mais je vois une objection ou du moins une difficulté qu'on vous opposera. Vous supposez un homme qui au fond est bon, ou du moins susceptible de s'amender, et qui tend vers le mieux. Mais si beaucoup de nos semblables (ceci est une manière de parler) étaient foncièrement mauvais, si leur nature ne les menait pas vers un progrès mais vers la dépravation. Une bonne police pourra au nom de l'humanité les empêcher de nuire et au besoin les supprimer, non les amender. Il faudrait pour agir sur leurs sentiments une police morale, c'est-àdire un clergé, imposant des lois à leur conscience. Mais au nom de quelle autorité ? Ou bien la foi en l'humanité, la volonté de se dévouer à son salut, resteront-elles le privilège d'une élite, seule véritablement morale, tandis que le commun des mortels se contentera comme aujourd'hui, de ne pas faire de scandale et de ne pas avoir de démêlés avec la justice. Un fait m'a frappé en lisant votre exposé, très remarquable, de l'évolution religieuse, c'est que la doctrine de l'État telle que l'ont définie les Allemands est une simple régression, qui par là même se trouve condamnée. Elle fait revivre en réalité le principe - et même les applications - de ces religions nationales que les mystères et le christianisme ont détruites.

(...)

The second paragraph of this letter shows us that Cumont used concepts from historiography of religion, i.e. religions nationales in opposition to the more advanced mystères and christianisme, to interpret the early $20^{\text {th }}$ century events. The religious legitimization of the War by Protestant historians of Christianity like Adolf von Harnack and Adolf Deissmann confirmed ideas which were already implicitly present in Les religions orientales: Christianity could not be the final step of the evolution towards a truly universal humanism. In fact, Cumont now seemed to doubt whether all people were capable of progress in the first place. In this, his views clearly differed from Loisy's, who remained more optimistic (cf. infra). 'Le commun des mortels', Cumont explained to Loisy, may not be able to attain the ideal of moral behavior through individual efforts. Most of them needed some sort of external motivation and control, which might be exerted by a 'bonne police.'

This particular episode of the correspondence beautifully illustrates the relation between Cumont's personal socio-cultural background and his ideas on history of (ancient) religions. On the one hand, his suggestion about the 'bonne police' reminds

39 For Cumont's indebtedness to Hegel, and a more comprehensive analysis of this letter to Loisy Bonnet, Van Haeperen 2006, xxiii-xxiv, xxxii-xxxiii, and passim; Bonnet 2011; Praet 2015, xvii, lii; Praet 2017. 
Cumont's views on the clergy of the religions orientales, with the pagan priests being some sort of 'directeurs de conscience' (Van Haeperen 2010). Cumont's conception of the pagan clergy, in turn, clearly reveals a Christian-centered (particularly Catholic) discourse which was typical for $19^{\text {th }}$ and early $20^{\text {th }}$ century historiography. Influenced by a Christian interpretation of religion, he commonly overestimated the importance of the 'interiorized faith' and the 'moral turn' of his religions orientales. On the other hand, Cumont's suggestion also bears resemblance to the crucial role he attributed to the philosophers in the religious evolution in Antiquity. They were essential instigators of changes in religious beliefs (Lannoy 2010). This letter furthermore shows Cumont's bourgeois background, when he explained that moral surveillance would be especially beneficial to the 'commun des mortels' and that, in the end, true moral perfection may only be possible for the elite. Here, too, we recognize the striking similarity of these ideas to his historiographical account of the religions orientales with their different forms of access to different levels of salvation for the élites and the foules.

\section{Letter 2: 'La société des nations ... selon moi c'est la cité sainte, la Jérusalem nouvelle'}

The following letter, ${ }^{40}$ written by Loisy on March 11,1918 , shows the same peculiar use of historic images to grasp the complex reality he was experiencing. The letter is a reply to a letter of Cumont's of March 8, $1918 .{ }^{41}$ In this letter, the Belgian scholar had pointed out that the internal conflicts which were ripping Europe apart, weakened European defense against foreign threats. At that time Loisy was working on his commentary on the New Testament. Apparently, his exegetical work triggered new views on the contemporary events:

Cher ami,

Paris, 11 mars 1918.

\section{(...)}

En traduisant l'Apocalypse, je me suis arrêté un bon moment devant le fameux passage : Elle est tombée, elle est tombée, Babylone la grande, - passage qui, d'ailleurs, est emprunté au livre d'Isaïe, - et je me disais que Babylone est encore en train de tomber, mais la Babylone de l'Europe moderne, avec tous ses empires qui mutuellement se saignent jusqu'à rester tous sur le carreau. J'avoue n’avoir pas pensé au péril jaune, qui me paraît encore assez lointain pour qu'il ne soit guère possible de prévoir comment, je veux dire en quelles conditions, l'humanité se jaunira. Ce qui est certain c'est que la civilisation européenne, la vieille civilisation chrétienne s'est portée à elle-même le coup qui lui fera céder la place à d'autres, et qu'on pourrait chanter déjà : Elle est tombée Babylone, sur tous les impérialismes de notre vieux monde. Ce doit être la fin de ce genre d'impérialisme. Il faut en finir avec l'impérialisme allemand, - et, même s'il était

40 Loisy to Cumont, March 11, 1918, BnF, NAF 15644, fo 181-182.

41 Cumont to Loisy, March 8, 1918, BnF, NAF 15651, fo 243. 
vainqueur il ne survivrait guère à sa victoire, - mais aucun des impérialismes voisins ne le remplacera. Ils auront tous reçu trop de plomb dans l'aile. C'est pourquoi la société des nations n'est peut-être pas une chimère, - selon moi c'est la cité sainte, la Jérusalem nouvelle, qui descend du ciel, parée comme l'épouse au jour des noces, - et ce pourrait être aussi bien la meilleure façon de prévenir le péril jaune. Après tout, si l'humanité doit devenir jaune, mieux vaut que la pauvre mette le temps à cette métamorphose et qu'elle la réalise pacifiquement. Inutile de vous dire que je me suis borné à faire ces réflexions et que je me suis bien gardé d'en tirer une nouvelle apocalypse, bien que j'en aie eu un petit moment la tentation.

(...)

Although Loisy didn't use the term 'national religion' in this specific letter, it is clear that he relies on the same framework as Cumont, and implicitly draws the same parallel: just like ancient Christianity had torn down the national barriers of the traditional pagan religions, the société des nations-which, according to Loisy, should be founded on the principles of a truly universal religion de l'humanité-would now replace the national Christian empires of Europe. ${ }^{42}$ Even if one of them would, at first, conquer the others, they were eventually doomed to fall, because they are all entirely insufficient for the new times and needs. The letter shows Loisy's hopes for the future, for the coming of a better kind of human which could replace the 'animal qui se croit intelligent.' The letters following the quoted letter reveal Cumont's and Loisy's dissension on this particular point. Although Loisy granted to Cumont that the present events seemed to speak against human progress, he still affirmed: 'somme toute, il y a, tout de même, une poussée ascendante de l'humanité, à travers d'infinis accrocs. ${ }^{33}$

\section{Conclusion}

By analyzing Cumont's and Loisy's ideas on the transition between paganism and Christianity in their published works and in their correspondence, we have tried to adopt a double viewpoint, in a way etic and emic, external and internal, or rather formal and informal, fixed and dynamic. The dialogue between these two different lieux de savoir proved to be fruitful to thoroughly explore the historiographical constructions of both scholars and to compare them. Such an approach has a great deal of insight to offer into our own reconstructions of the past in as much as we inherited at least part of the narratives created by our scientific 'ancestors'. The analysis of the compositional, terminological and conceptual choices made by Cumont and Loisy, together with the general framework of their work, enlightened the process of 'creation' of religions and religion in a specific historical context, both ancient and modern. In fact the reassess-

42 We should of course underline that German Protestant scholars of religion expressed similar hopes for a religion which could transcend national differences. See for instance Adolf Deissmann's commitment to the ecumenical movement, which was, however, still explicitly Christian (which is no longer the case for Loisy).

43 Loisy to Cumont, February 23, 1919, BnF, NAF 15644, fo 198. 
ment of the past, in our case the question of how paganism influenced the emergence of Christianity, cannot be disconnected from the challenge of the present: the progress of humanity, the tension between war and peace, the emancipation of mankind, etc. Any narrative on Antiquity is, in short, a discourse on the present, with its ideological burden. The use of semi-private sources, like the letters, plays a valuable part in highlighting the fluidity of historiographical creations. They enable us to observe the doubts, paradoxes, corrections, nuances that any scientific creation entails. They validly bring complexity in the reconstruction of scientific genealogies and show how the progress of knowledge is a relational phenomenon.

\section{Bibliography}

Amsler, Frédéric (ed.) 2013. Quelle place pour Alfred Loisy dans l'histoire de la recherche en exégèse biblique et en sciences des religions? Mythos. Rivista di Storia delle religioni 7.

Auffarth, Christoph 2006. "'Licht vom Osten": Die antiken Mysterienkulte als Vorläufer, Gegenmodell oder katholisches Gift zum Christentum', Archiv für Religionsgeschichte 8. 206-226.

Auffarth, Christoph 2013. 'Mysterien (Mysterienkulte)', Reallexikon für Antike und Christentum 25. $422-471$.

Belayche, Nicole 2000. 'L'Oronte et le Tibre: "L'Orient” des cultes “orientaux" de l'empire romain.' In L'Orient dans l'histoire religieuse de l'Europe. L'invention des origines, ed. M.A. Amir-Moezzi et John Scheid. Turnhout. 1-35.

Belayche, Nicole; Massa, Francesco (eds.) 2016. Les “ mystères" ? Questionner une catégorie. Métis. Anthropologie des mondes grecs anciens 14. Paris.

Bonnet, Corinne 1997. La correspondance scientifique de Franz Cumont conservée à l'Academia Belgica de Rome. Bruxelles-Rome.

Bonnet, Corinne 2005. Le 'grand atelier de la science'. Franz Cumont et l'Altertumswissenschaft. Des études universitaires à la fin de la ${ }^{\mathrm{e}}$ Guerre mondiale (1888-1923). Bruxelles-Rome.

Bonnet, Corinne 2010. 'Lux perpetua: un testament spirituel ?' In Rome et ses religions: culte, morale et spiritualité. En relisant Lux Perpetua de Franz Cumont, ed. Corinne Bonnet, Carlo Ossola, John Scheid. Mythos. Rivista di Storia delle Religioni suppl. 1. 125-141.

Bonnet, Corinne 2011. 'Les dernières volontés du paganisme expirant': Franz Cumont and "The Decline and Fall of Roman Paganism"', Papers of the Nineteenth-Century Theology Group AAR XLII. 91-107.

Bonnet, Corinne; Rüpke, Jörg; Scarpi, Paolo (eds.) 2006. Religions orientales-culti misterici. Neue Perspektive-nouvelles perspectives-prospettive nuove. Stuttgart.

Bonnet, Corinne; Van Haeperen, Françoise 2006. 'Introduction historiographique.' In Cumont 2006, xi-lxxiv.

Bonnet, Corinne; Pirenne-Delforge, Vinciane; Praet, Danny (eds.) 2009. Les religions orientales dans le monde grec et romain: cent ans après Cumont (1906-2006). BHIR. Brussels-Rome.

Bruhns, Hinnerk 2005. 'Mikhail I. Rostovtzeff et Max Weber: une rencontre manquée de l'histoire avec l'économie', Anabases 2. 79-99.

Burkert, Walter 1987. Ancient Mystery Cults. Cambridge, MA and London.

Cumont, Franz 1935. 'L’Histoire des Religions', Le Flambeau 18/9. 291-294.

Cumont, Franz 2006. Les religions orientales dans le paganisme romain, ed. Corinne Bonnet, Françoise Van Haeperen. Bibliotheca Cumontiana, Scripta Maiora I. Torino.

Cumont, Franz 2013. Les Mystères de Mithra, ed. Nicole Belayche, Attilio Mastrocinque. Bibliotheca Cumontiana, Scripta Maiora III. Rome-Torino. 
Cumont, Franz 2015. Astrologie, ed. Danny Praet, Béatrice Bakhouche. Bibliotheca Cumontiana, Scripta Minora IV. Rome.

Gooch, Todd 2000. The Numinous and Modernity: An Interpretation of Rudolf Otto's Philosophy of Religion. Berlin and New York.

Jones, Alan A. 1983. Independence and Exegesis. The Study of Early Christianity in the Work of Alfred Loisy (1857-1940), Charles Guignebert (1857-1939) and Maurice Goguel (1880-1955). Tübingen.

Krech, Volkhard 2002. Wissenschaft und Religion. Tübingen.

Lannoy, Annelies 2010. 'Les masses vulgaires et les intelligences élevées. Les agents de la vie religieuse dans Lux Perpetua et leur interaction.' In Rome et ses religions: culte, morale et spiritualité. En relisant Lux Perpetua de Franz Cumont, ed. Corinne Bonnet, Carlo Ossola, John Scheid. Mythos. Rivista di Storia delle Religioni suppl. 1. 63-82.

Lannoy, Annelies 2011. 'La correspondance bilatérale entre Alfred Loisy et Franz Cumont: brève présentation et projet d'édition', Anabases. Traditions et Réceptions de l'Antiquité 13. 261-265.

Lannoy, Annelies 2012. Het christelijke mysterie. De relatie tussen het vroege christendom en de heidense mysterieculten in het denken van Alfred Loisy en Franz Cumont, in de context van de modernistische crisis. Diss. Gent.

Lannoy, Annelies 2013. 'Comparing words, myths and rituals: Alfred Loisy, Franz Cumont and the case of “Gaionas le deipnokritès".' In Amsler 2013, 154-186.

Lannoy, Annelies; Praet, Danny (eds.) 2018. The Christian Mystery. Early Christianity and the Pagan Mystery Cults in the Work of F. Cumont and in the History of Scholarship. Stuttgart.

Laplanche, François 1999. 'L'histoire des religions en France au début du XX'e siècle', MEFRIM 111/2. 623-634.

Laplanche, François 2006. La crise de l'origine. Paris.

Laplanche, François; Biagioli, Ilaria; Langlois, Claude (eds.) 2007. Alfred Loisy cent ans après. Autour d'un petit livre. Turnhout.

Lavagne, Henri 2000. 'Lettres inédites de Franz Cumont à Salomon Reinach', CRAI 144/2. 763-774.

Otto, Rudolph 1917. Das Heilige: Über das Irrationale in der Idee des Göttlichen und sein Verhältnis zum Rationalen. Breslau.

Loisy, Alfred 1909. Leçon d'ouverture du cours d'histoire des religions au Collège de France. Paris. Loisy, Alfred 1917. La Religion. Paris.

Loisy, Alfred 1930. Les mystères païens et le mystère chrétien. Paris [1919]1.

Masuzawa, Tomoko 2005. The Invention of World Religions. Or how European Universalism was preserved in the Language of Pluralism. Chicago.

Matern, Harald; Dietz, Thorsten (eds.) 2012. Rudolf Otto: Religion und Subjekt. Zurich.

Melissa, Raphael 1997. Rudolf Otto and the Concept of Holiness. Oxford.

Oexle, Otto Gerhard (ed.) 2001. Das Problem der Problemgeschichte 1880-1932. Göttingen.

Praet, Danny 2011. 'Franz Cumont, the Oriental Religions, and Christianity in the Roman Empire: A Hegelian View on the Evolution of Religion, Politics, and Science', Papers of the Nineteenth-Century Theology Group AAR XLII. 133-158.

Praet, Danny 2012. 'Wird rein durch Feuer, Wasser, Luft und Erden: Teleologie, universalisme et de symboliek van de elementen in de godsdienst-filosofie van Franz Cumont.' In Door denken en doen: essays bij het werk van Ronald Commers, ed. Tom Claes. Gent. 177-219.

Praet, Danny 2013. 'Symbolisme, évolution rituelle et morale dans l'histoire des religions: le cas du Taurobolium dans les publications et la correspondance de Franz Cumont et d'Alfred Loisy.' In Amsler 2013, 127-142.

Praet, Danny 2014. 'Oriental Religions and the Conversion of the Roman Empire: The Views of Ernest Renan and of Franz Cumont on the Transition from Traditional Paganism to Christianity.' In Competition and Religion in Antiquity, ed. David Engels, Peter Van Nuffelen. Brussels. 285-307. 
Praet, Danny 2015. 'Le "problème de l'astrologie" dans le contexte idéologique de l'affaire Cumont: les relations entre religion et sciences dans l'Antiquité et dans les universités d'État belges.' In Cumont 2015, xliii-Ivii.

Praet, Danny 2017. 'The End of Ancient Paganism and the End of Modern Organized Religion in the Thought of Franz Cumont.' In When a Religion Comes to an End... Political and Social Factors in the Demise of Religions, ed. Anne Morelli and Jeffrey Tyssens. Leuven-Brussel (forthcoming).

Praet, Danny; Bonnet, Corinne (eds.) 2017. Science, politique et religion à l'époque de la crise moderniste. BHIR. Brussels-Rome.

Praet, Danny; Lannoy, Annelies 2017. 'Alfred Loisy's Comparative Method in Les mystères païens et le mystère chrétien', Numen 64.64-96.

Reinach, Salomon 1909. Orpheus. Histoire générale des religions. Paris.

Reitzenstein, Richard 1910. Die hellenistischen Mysterienreligionen nach ihren Grundgedanken und Wirkungen. Leipzig.

Renan, Ernest 1882. Histoire des origines du christianisme. VI. Marc-Aurèle et la fin du monde antique. Paris.

Rey, Sarah 2010. 'Les Religions orientales en mouvement. Les ratures de Franz Cumont.' In Rome et ses religions: culte, morale et spiritualité. En relisant Lux Perpetua de Franz Cumont, ed.

Corinne Bonnet, Carlo Ossola, John Scheid. Mythos. Rivista di Storia delle Religioni suppl. 1. 21-32.

Roessli, Jean-Michel 2013. 'Les mystères païens et le mystère chrétien d'Alfred Loisy (1857-1940) et sa place dans les débats sur les origines du christianisme au début du XXe siècle.' In Amsler 2013, 73-95.

Sand, Erik R. 1999. 'Comparative Religion: Between Phenomenology and Typology of Religions.' In Comparative Studies in History of Religions. Their Aim, Scope and Validity, ed. Erik R. Sand, Jørgen Podemann Sørensen. Copenhagen. 109-120.

Scheerlinck, Eline; Praet, Danny; Rey, Sarah 2016. 'Race and Religious Transformations in Rome. Franz Cumont and Contemporaries on the Oriental Religions', Historia 65.2. 220-243.

Scheerlinck, Eline; Rey, Sarah; Praet, Danny 2014. 'Analogies curieuses et ressemblances frappantes. Des antiquisants face à l'impérialisme français en Méditerranée', Forum Romanum Belgicum 7. 1-14.

Sharpe, Eric J. 1994. Comparative Religion. A History. London.

Strenski, Yvan 2003. Theology and the First Theory of Sacrifice. Numen 98. Leiden-Boston.

Smith, Jonathan Z. 1990. Drudgery Divine. On the Comparison of Early Christianities and the Religions of Late Antiquity. London.

Talar, C. J.T. 2015. 'Alfred Loisy and the Great War.' In Roman Catholic Modernists Confront the Great War, ed. C.J.T. Talar, Lawrence F. Barmann. New York. 16-52.

Talar, C. J.T. 2017. 'Salomon Reinach's Orpheus: Catalyst for Debate over the History of Religions in France.' In Praet, Bonnet, 2017.

Tylor, Edward B. 1874. Primitive Culture. Researches into the Development of Mythology, Philosophy, Religion, Language, Art and Custom. New York.

Van Haeperen, Françoise 2007. 'La réception des Religions orientales de Fr. Cumont: l'apport des comptes rendus', Anabases 6. 159-185.

Van Haeperen, Françoise 2010. 'Des “médecins de l'âme”. Les prêtres des Religions orientales selon Cumont.' In Rome et ses religions: culte, morale et spiritualité. En relisant Lux Perpetua de Franz Cumont, ed. Corinne Bonnet, Carlo Ossola, John Scheid. Mythos. Rivista di Storia delle Religioni suppl. 1. 49-62. 